See discussions, stats, and author profiles for this publication at: https://www.researchgate.net/publication/341713646

\title{
The Social Perils and Promise of Remote Work
}

Article in SSRN Electronic Journal · January 2020

DOI: 10.2139/ssn. 3613235

CITATION

1

1 author:

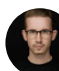

Phil Lord

McGill University

22 PUBLICATIONS 6 CITATIONS

SEE PROFILE

Some of the authors of this publication are also working on these related projects:

COVID-19 View project

Project Poverty and Inequality View project
READS

93 


\title{
The social perils and promise of remote work
}

\author{
Phil Lord ${ }^{1 *}$
}

\begin{abstract}
The COVID-19 pandemic has transformed daily life, notably by forcing billions of people to work from home. As restrictions related to the pandemic are eased, companies are reconsidering their real estate footprint and contemplating a long-term move to remote work. This paper takes an in-depth look at this move. It argues that remote work is, like other consequences and aspects of the pandemic, deeply rooted in broader social issues. The move to remote work has the potential to alleviate historic inequities which arise from the demands of the modern workplace - demands which have led women to occupy lower-paying positions. It also argues that the move to remote work can contribute to the increasing precarity of work, by shifting the cost of workspace from employers to employees. It suggests governmental solutions, rooted in law and behavioural economics, which could maximise its potential and protect workers from its perils.
\end{abstract}

JEL Classification: J81; J88; K31

Keywords

COVID-19 - remote work - precarious work - labor law

${ }^{1}$ Faculty of Law, McGill University

*Corresponding author: phil.lord@mail.mcgill.ca

\section{Introduction}

The COVID-19 pandemic has disrupted daily life across the world. To contain the spread of COVID-19, governments have ordered the shutdown of broad sections of the economy (Lord $\&$ Saad, 2020, p.17). In response to sudden revenue decreases, many businesses have opted to at least temporarily lay off their workers. Losing one's job has more than financial consequences. It often means losing the significance drawn from the connections one builds at work and the sense of contribution to one's household, profession, and community. During the pandemic, government measures to subsidise payrolls have been late and insufficient: millions have lost their job (Lord, 2020, pp. 4-5). Those fortunate enough to keep theirs have had to adapt, most notably by working from home. While restrictions are being eased around the world, a return to life as we knew it will only happen when a vaccine is developed, which will take months or years (Gillies, 2020).

As a result, office towers in large cities are almost empty - and may remain underoccupied for the foreseeable future. In the midst of a recession caused by the pandemic, companies are rethinking their use of real estate. If their workers could work from home for several months, then they likely can do so after the pandemic as well. Renting tens of thousands of square feet of prime office space in large cities no longer seems to be a necessity (Haag, 2020). The pandemic will accelerate an existing trend of companies increasingly allowing their employees to work from home. ${ }^{1}$

\footnotetext{
${ }^{1}$ For instance, in the United States, the number of workers who work from home at least half of the time has almost tripled since 2005, see generally Global Workplace Analytics 2020, which aggregates data from the United
}

The move to remote work is deeply rooted in much broader social issues. As will be argued below, it has to potential to alleviate historic inequities which arise from the demands of the modern workplace, but also to contribute to the increasing precarity of work. It is therefore crucial that governments thoughtfully approach this development, to maximise its potential and protect workers from its perils.

\section{The promise of remote work}

The move to remote work has the potential to be the most transformative labour change in a generation. Over the past decade, companies have begun to allow their workers to work from home (more so in certain industries) (Greenbaum, 2019). This move has, in part, been a response to requests by some employees. Remote work affords employees more flexibility regarding when they work and a greater opportunity to spend time with their loved ones. More importantly, remote work challenges historic and structural inequities which arise from the nature and expectations of the modern workplace. The need to commute and work from an office at set hours of the day can be inconsistent with the demands of one's family or childcare responsibilities. As women have historically borne a disproportionate share of child-rearing and household responsibilities, they have often had to say no to higher-paying, higher-level positions and careers (Gangl \& Ziefle, 2009). This has, in part, led to the pernicious wage gap even the wealthiest countries on Earth grapple with. The persistence of the wage gap can be partly explained by these underlying

States government. 
issues, which lead women to, albeit indirectly, often choose to earn less.

The COVID-19 pandemic will have incentivised a positive development. The move to remote work has the potential to significantly ease work-life integration, and to help address the gap between the earnings of women and men. As mentioned above, companies also have a significant financial incentive to favour remote work. If employees work from home at least some days of the week, then the need for office space decreases. Companies, especially those in industries which typically have a significant real estate footprint in expensive markets (such as law and financial services), stand to meaningfully reduce their fixed costs and, thereby, unlock shareholder value (Haag, 2020; Simmons, 2020).

\section{The perils of remote work}

If the only consequences of a reduction in corporate real estate footprints were those set out above, there would not be much governments should do to modulate current incentives. However, a reduction in these footprints also has the potential to redefine employment relationships and contribute to the increasing precarity of work. It is therefore important for governments to get ahead of these changes and proactively create incentive structures which maximise the potential benefits of remote work, protect employees, and preserve a just allocation of employment costs between employers and employees.

The most immediate effect of remote work, and the corresponding decrease in real estate footprints, will be to pad corporate bottom lines. There is nothing intrinsically wrong with that. The creation of shareholder value benefits shareholders, who may be employees of the corporation or retirement funds whose beneficiaries are everyday individuals. It would, however, be foolish to assume that companies will use the value unlocked to directly benefit their employees. Absent incentives to do so, companies generally seek to reward their shareholders through dividend payments and stock buybacks. For instance, when promoting his landmark tax reform proposal, United States President Donald Trump stated that a reduction in corporate tax rates would benefit workers. Unsurprisingly, almost none of the benefits went to workers (Lord \& Saad, 2020, p. 27).

Yet the transition to remote work will arguably generate additional costs for employees. Many of us remember a 2017 BBC interview during which a professor's child entered his home office, only to be dragged out by the professor's wife (BBC News, 2017). While many employees may gladly work from home, doing so requires them to purchase equipment (computers, monitors, telecommunication systems, and so forth). Video or voice communications with coworkers and clients also often require them to have a home office, or a room where they can be undisturbed for long periods of time. The reduction in corporate office space is likely to cause a concurrent increase in home sizes, especially in large cities where homes may be particularly small. In these cities, the cost of an additional room may be quite significant.
Under the current framework, employees are responsible for these costs. Employers have no obligation to contribute. The move to remote work can therefore be conceptualised as a reallocation of the cost of workspace from employers to employees. This reallocation will likely contribute to the increasing precarity of work, through a reduction in the net income of employees. Over the last decade, we have witnessed an increase in the use of contracting relationships as replacements for employment relationships, leading to the advent of the so-called "gig economy" - defined by the rise of companies such as Uber. ${ }^{2}$ By using contracting relationships, employers can avoid a number of costs related to employment relationships. Contractors are indeed generally not subject to worker protection rules, which notably regulate minimum wage, leave, severance, and overtime pay (Lord \& Saad, 2020, p. 24). They also do not receive pension and other benefits. By classifying employees as independent contractors, employers are able to shift these costs to those who work for them. They are, in fact, incentivised to do so (as it creates shareholder value). We can conceptualise remote work as a further shifting of costs from employers to employees, which contributes to the increasing precarity of work.

\section{Government approaches to the transition to remote work}

Governments should act to incentivise a fairer allocation of costs between employers and employees. As mentioned above, the move to remote work can be a positive development - one that should be encouraged. It can help make the nature of work fairer by alleviating its disproportionate impact on women. Governments should nonetheless ensure that the move to remote work does not result in an inequitable reallocation of the cost of workspace from employers to employees.

Various taxation mechanisms could help both incentivise a fair such allocation and reduce the burden on individual employees. Governments should, first, allow employees to deduct the cost of their home office from their income for taxation purposes. Currently, independent contractors have access to a broader range of deductions than employees. ${ }^{3}$ Regardless of the proposals I set forth below, it is likely that we will see a system which at least partly allocates the cost of workspace to employees. This allocation challenges the notion that salaried workers do not have work-related expenses (unlike contractors) and justifies such a deduction. Better yet, a tax credit could allow employees to fully deduct the cost of their home office from their income tax payable, reducing its net cost

\footnotetext{
${ }^{2}$ Uber's ride-hailing app is available in 63 countries. Uber works with 3.8 million "driver-partners," all of whom are contractors (Lord \& Saad, 2020, p. 24). For data on the growing importance of the gig economy, see Berg (2016, pp. 543-44) and Jeon et al. (2019).

${ }^{3}$ See for example Kraus \& Barella (2014). In most developed countries, home office expenses are only deductible where an employee's employment contract mandates the use of a home office. It is worth noting that Australia has made a commendable effort to allow employees to deduct these expenses even when their employment contract does not mandate the use of a home office, see Australian Taxation Office 2020.
} 
to zero. ${ }^{4}$ To compensate the tax shortfall and reallocate the cost back to employers, governments could raise taxes paid by employers, such as payroll taxes. This reallocation could be lower than the cost of renting office space, in order to incentivise companies to encourage remote work. Regardless, it is likely that the cost of home offices, for employees who often live in lower-cost areas of a city or in neighbouring cities, will be lower than the cost of renting office space in the downtown core of large cities. Additionally, even without a reallocation of this cost, the move to remote work will likely result in greater participation of women in the workforce, which could significantly increase tax revenue.

Governments need to play a role in incentivising a positive move to remote work. That is not to say that self-regulation by private actors has been ineffective. The rise of corporate social responsibility (CSR), broadly defined as "a form of international private self-regulation focused on the reduction and mitigation of industrial harms and provision of public good moves" (Sheehy, 2015, p. 643), has defined the past decade. CSR justifies corporate behaviour which considers a broad range of actors (beyond shareholders) and seeks to maximise outcomes beyond profit, such as employee wellbeing or environmental sustainability. CSR need not rely on irrational behaviour. While it does move past a narrow understanding of rational economic behaviour as profit maximisation, it recognises that an economic entity exists within a broader context which it must take into account in its decision-making. CSR offers a more realistic and pragmatic model where a company perceives "benefit as the sum of economic, social and psychological benefits" (Guzavicius et al., 2014, p. 523). As market actors such as investors incorporate these aims into their decision making, the flow of capital incentivises companies to respect CSR principles. As an example of CSR, during the pandemic and its economic downturn, certain companies, such as Slack and Facebook, have voluntarily chosen not to lay off any employees (Lord \& Saad, 2020, p. 19). The seriousness of the potential impact of the move to remote work requires government attention. Governments should build upon the rise and power of CSR in addressing this challenge.

For instance, governments could mandate disclosure by companies of their use of employment relationships which shift the cost of workspace to employees. ${ }^{5}$ Cass Sunstein argues that disclosure is a necessary component of freedom. For actors to exercise their freedom of choice, they must have access to the information which they use in their decisionmaking. 6 The disclosures I propose regarding cost shifting would mirror existing rules, which have been used to incen-

\footnotetext{
${ }^{4}$ On the distinction between a tax deduction and a tax credit, see Sunley (1977) and Pogue (1974). A tax credit reduces an individual's tax liability. A $\$ 500$ tax credit reduces a $\$ 3,000$ tax liability to $\$ 2,500$. In contrast, a tax deduction reduces taxable income. A $\$ 5,000$ credit reduces a taxable income of $\$ 50,000$ to $\$ 45,000$. The latter amount is then taxed. The tax savings are the product of the individual's marginal tax rate and the difference (here, $\$ 5,000)$.

${ }^{5}$ Disclosure systems can create strong incentives at a relatively low cost, see for example Coffee (1974) and Bertrand \& Morse (2011).

${ }^{6}$ See generally Sunstein (2019).
}

tivise certain corporate behaviour. The closest example would be the Dodd-Frank Wall Street Reform and Consumer Protection Act of 2010, which requires public companies to disclose the ratio between the compensation of their executives and that of their median employee (Lifshey, 2018; Bebchuk, Cremers, $\&$ Peyer, 2011). The mandated disclosures would help consumers and other private actors make decisions about which companies they do business with. As these actors disengage with companies whose policies they disagree with, the companies (and others with similar practices) would be strongly incentivised to change their behaviour.

Governments could also aggregate these disclosures on government websites, thereby rendering access easier for private actors. Even if they do not, self-interested private actors might distill and aggregate this information on their own websites. ${ }^{7}$ Regardless of the means, the effectiveness of CSR increases as more actors become familiar with it and access to information is further democratised.

Another avenue to consider are less traditional solutions to "shame" companies which adopt policies governments seek to disincentivise. Governments play a role in defining what Cass Sunstein calls "social meanings" (Sunstein, 2020). The rise of CSR, analysed above, is an example of a change in social meanings - a redefinition of profit maximisation and of the role of companies. Sunstein notes that governments play a role in defining and altering social meanings. Presidents have long used their position, and its correlative media attention, to alter social meanings and (dis)incentivise certain behaviour. President Trump has used his proverbial "bully pulpit" to, notably, shame companies that outsource jobs to other countries (Rushe, 2017). Active government promotion of CSR or shaming of companies which shift the cost of workspace to their employees, has the potential to be highly effective in driving corporate behaviour. That is especially true as the social meaning of remote work may currently be, overall, positive. Remote work responds to the needs of employees and provides them with flexibility. Governments can help nuance this social meaning, noting that, while remote work does respond to the needs of employees, it can also be detrimental if the cost of workspace is shifted to employees.

\footnotetext{
${ }^{7}$ In a piece published in the Wall Street Journal, Cass Sunstein and Richard Thaler argue for more extensive disclosure by credit card companies. Regarding the disclosures they propose, they analogously argue:

To be sure, most consumers would not read these [disclosure] files in any detail. Instead we anticipate that new third-party Web sites would compete for the business of distilling the information in the files. The Web sites would serve three purposes. First, they would translate the information into plain English. Second, they would explain to consumers how they could save money by changing their behavior. And third, they would point consumers to alternative providers that, given their past behavior, would provide a better deal (Sunstein \& Thaler, 2008).
} 


\section{Conclusion}

The COVID-19 pandemic has altered our lives. That much will be true for the foreseeable future. More fundamentally, the pandemic has forced us to reconsider various aspects of how we do things: how we combat unemployment during crises (Lord, 2020), and how and where we draw the line between the role of governments and that of private actors (Lord \& Saad, 2020). Beyond governments and governance, the pandemic has exposed the inadequate financial flexibility of our small businesses (Lord \& Saad, 2020, p. 16) and will likely accelerate the move to non-physical interactions, most notably through the increasing roles of e-commerce and remote work.

This paper has taken a more in-depth look at the move to remote work. It argued that remote work is, like other consequences and aspects of the pandemic, deeply rooted in broader social issues. The move to remote work has the potential to alleviate historic inequities which arise from the demands of the modern workplace - demands which have led women to occupy lower-paying positions. This paper also argued that the move to remote work can contribute to the increasing precarity of work, by shifting the cost of workspace from employers to employees. It suggested governmental solutions, rooted in law and behavioural economics, which could maximise its potential and protect workers from its perils.

\section{Acknowledgments}

I gratefully acknowledge financial support from Canada's Social Sciences and Humanities Research Council. I am also grateful to Michelle Baddeley, Lydia Saad, and an anonymous reviewer for thoughtful comments.

\section{References}

Australian Taxation Office (2020). Home Office Expenses. Accessed 5 June 2020. Available at www.ato.gov.au/indi viduals/income-and-deductions/deductions-you-canclaim/home-office-expenses/.

BBC News (2017). Children interrupt BBC News interview. BBC News. Accessed 16 May 2020. Available at www.youtube.com/watch?v=Mh4f9AYRCZY.

Bebchuk, Lucian A., Martijn Cremers, \& Urs Peyer (2011). The CEO Pay Slice. Journal of Financial Economics, 102(1), 199-221.

Berg, Janine (2016). Income Security in the On-Demand Economy: Findings and Policy Lessons From a Survey of Crowdworkers. Comparative Labor Law \& Policy Journal, 37(3), 543-576.

Betrand, Marianne \& Adair Morse (2011). Information Disclosure, Cognitive Biases, and Payday Borrowing. The Journal of Finance, 66(6), 1865-1893.
Coffee, John C. (1984). Market Failure and the Economic Case for a Mandatory Disclosure System. Virginia Law Review, 70(4), 717-753.

Gangl, Markus \& Andrea Ziefle (2009). Motherhood, Labor Force Behavior, and Women's Careers: An Empirical Assessment of the Wage Penalty for Motherhood in Britain, Germany, and the United States. Democracy, 46(2), 341-369.

Gillies, Rob (2020). Canada unlikely to return to normal until there is a COVID-19 vaccine. PBS News, April 9. Available at www.pbs.org/newshour/health/canadaunlikely-to-return-to-normal-until-there-is-a-covid-19vaccine.

Global Workplace Analytics (2020). Latest Work-At-Home/ Telecommuting/Mobile Work/Remote Work Statistics. Available at globalworkplaceanalytics.com/telecommu ting-statistics.

Greenbaum, Zara. (2019). The future of remote work. Monitor on Psychology, 50(9), 54-60.

Guzavicius, Andrius, Rita Vilkè, \& Vytautas Barkauskas (2014). Behavioural Finance: Corporate Social Responsibility Approach. Procedia: Social and Behavioral Sciences, 156, 518-523.

Haag, Matthew (2020). Manhattan Faces a Reckoning if Working From Home Becomes the Norm. New York Times, May 12. Available at www.nytimes.com/2020/05 /12/nyregion/coronavirus-work-from-home.html.

Jeon, Sung-Hee, Huju Liu, \& Yuri Ostrovsky (2019). Measuring the Gig Economy in Canada: Using Administrative Data. Catalogue No 11F0019M. Ottawa: Statistics Canada.

Kraus, Richard J., \& Vincent R. Barrella (2014). Deductibility of Business Expenses: The Employee/Independent Contractor Controversy. North East Journal of Legal Studies, 31, 28-49.

Lifshey, Deb (2018). The CEO Pay Ratio: Data and Perspectives from the 2018 Proxy Season. Harvard Law School Forum on Corporate Governance. Available at corpgov.law.harvard.edu/2018/10/14/the-ceo-pay-ratiodata-and-perspectives-from-the-2018-proxy-season/.

Lord, Phil, \& Lydia Saad (2020). Tackling the COVID-19 Pandemic (under peer review). SSRN Preprint. Available at ssrn.com/abstract $=3554436$.

Lord, Phil. (2020). Incentivising Employment during the COVID-19 Pandemic (forthcoming). The Theory and Practice of Legislation. Available at ssrn.com/abstract= 3573176. 
Pogue, Thomas F. (1974). Deductions vs. Credits: A Comment. National Tax Journal, 27(4), 659-662.

Rushe, Dominic (2017). Auto industry's Trump fear: 'Everyone dreads being subject of a tweet.' The Guardian, January 7. Available at www.theguardian.com/business/20 17/jan/07/auto-industry-donald-trump-twitter-jobs-out sourcing-mexico.

Sheehy, Benedict (2015). Defining CSR: Problems and Solutions. Journal of Business Ethics, 131(3), 625-648.

Simmons, Christine (2020). Law Firm Leasing Activity Craters as Industry Rethinks Its Real Estate Footprint. The American Lawyer, May 19. Available at www.law. com/americanlawyer/2020/05/19/law-firm-leasing-acti vity-craters-as-industry-rethinks-its-real-estate-footprint/.

Sunley, Emil M. (1977). The Choice Between Deductions and Credits. National Tax Journal, 30(3), 243-247.

Sunstein, Cass R. \& Richard H. Thaler (2008). Disclosure Is the Best Kind Of Credit Regulation. The Wall Street Journal, August 13. Available at www.wsj.com/articles/ SB121858695060335079.

Sunstein, Cass R. (2019). On Freedom. Princeton: Princeton University Press.

Sunstein, Cass R. (2020). The Meaning of Masks. Journal of Behavioral Economics for Policy, 4(S), 5-8. 